\title{
Morphometric and Stereologic Analysis of Chlorella vulgaris Under Heterotrophic Growth Conditions
}

\author{
F. MARTÍNEZ*, C. ASCASO† and M. I. ORÚS* \\ * Departamento de Biologia (C-XI), Facultad de Ciencias, Universidad Autónoma de Madrid, 28049 Madrid, \\ and $\dagger$ Instituto de Edafologia y Biologia Vegetal, C.S.I.C., Serrano 115 bis, 28006 Madrid, Spain
}

Accepted: 8 November 1990

\begin{abstract}
A computer-supported determination of stereological parameters was used to study the possible ultrastructural changes of Chlorella vulgaris UAM I0I under photolithotrophic, mixotrophic and photoheterotrophic conditions of growth. Data recording was carried out through a semi-automatic digitizing image analysis system instead of the current method of superimposition of an array of short lines.

Glucose promoted drastic physiological changes [Martinez and Orús. 1991. Plant Physiology (in press)], which strongly affected the size of the cells and volume densities of storage materials. However, volumetric ratios of the mitochondrion or chloroplast active fraction were not affected by the presence of glucose, probably indicating that these ratios are characteristic of each species.

Cell wall ultrastructure was also analysed and the presence of sporopollenin demonstrated, in contrast to the thin and sporopollenin-lacking cell wall generally described for Chlorella vulgaris species.
\end{abstract}

Key words: Chlorella vulgaris, photoautotrophic, mixotrophic, photoheterotrophic, image analysis, stereology.

\section{INTRODUCTION}

Among the heterotrophic algae isolated from the effluent of a sugar refinery, as part of a search for microalgae exhibiting high heterotrophic potential for liquid organic waste treatment, a wild strain of Chlorella (UAM 10l) was found to be the best adapted to its organic environment (Martínez et al., 1987). The high performance of this strain under heterotrophic conditions can be related to two physiological adaptations that allow this alga to use the glucose in its natural habitat efficiently: the glucose uptake system is not photosensitive and mitochondrial respiration is not affected by light (Martínez and Orús, 1991). The ability of UAM 101 to use different organic compounds (Martínez et al., 1987), together with some structural data that we will present in this paper, indicate that this strain can be classified as a Chlorella vulgaris. This point has kindly been confirmed by Professor E. Kessler, University of Erlangen, who classified it as Chlorella vulgaris Beijerinck, var. vulgaris.

Some interesting work has already been carried out on the ultrastructure of the genus Chlorella (Atkinson, Gunning and John, 1972; Atkinson, John and Gunning, 1974; Pickett-Heaps, 1975; Raven, 1980; Yamada and Sakaguchi, $1982 a, b$; Rosen, Berliner and Petro, 1985). In most cases, these data were combined with physiological and biochemical studies for taxonomic purposes (Atkinson $e t$ al., 1972, 1974; Kessler, 1978; Yamada and Sakaguchi, 1982b). This kind of study facilitates the reliable identification of strains, thereby permitting comparison of theoretical research with applied studies on algae. In the light of the above-mentioned physiological features of strain UAM 101, we were interested to know whether or not it possessed ultrastructural differences from the iconotype. However, the main objective of this work was the study of the ultrastructural changes promoted by glucose in this facultative heterotroph since, as far as we know, most of the ultrastructural studies with organic substrates have been carried out with obligate heterotrophs (Burton and Moore, 1974; Gaffal, 1978).

This paper reports stereological data obtained from software-based image analysis. Data were recorded through a semi-automatic digitizing image analysis system on electron micrographs of strain UAM 101 of Chlorella vulgaris grown under photolithotrophic conditions, as well as in the presence of glucose and light.

\section{MATERIALS AND METHODS}

\section{Organism}

Chlorella vulgaris UAM 101 is a wild strain isolated from the effluent of a sugar refinery located in Aranjuez (Madrid, Spain). This strain has been incorporated in the Göttingen University Collection of Algae under the number SAG 9.88.

\section{Culture conditions}

Batch cultures were grown in 0.5-1 Erlenmeyer flasks containing $200 \mathrm{ml}$ of a medium described by RodríguezLópez (1964), at $25^{\circ} \mathrm{C}$, under continuous illumination with $150 \mu \mathrm{E} \mathrm{m}^{-2} \mathrm{~s}^{-1}$ (F33 cool-white fluorescent lamps $40 \mathrm{~W}$; OSRAM, Madrid, Spain). Initial cell density was $50 \mu \mathrm{g} \mathrm{d}$. wt ml $\mathrm{m}^{-1}$, using photoautotrophic (AC) cells in the exponential growth phase as inoculum in each case. Mixotrophic (MX) and photoheterotrophic (PH) cultures 
TABLE 1. Size of Chlorella vulgaris UAM 101 under different conditions of growth considering the maximum diameters $\left(\mathrm{D}_{\max } \mu \mathrm{M}\right)$ (relevant for ellipsoidal shape forms) of vegetative cells, sporangia or autospores inside mother cells. Shape tendency of each subpopulation considered was determined by form perimeter and area indicators (see footnotes to this table)

\begin{tabular}{|c|c|c|c|c|c|c|c|c|c|}
\hline & & & & & rowth condit & & & & \\
\hline & & $\mathrm{AC}$ & & & $\mathrm{MX}$ & & & $\mathrm{PH}$ & \\
\hline & $D_{\max } \pm \mathbf{s . d}$ & $\mathrm{FPI}^{*} \pm$ s.c. & FAI $\dagger \pm$ s.e. & $\mathrm{D}_{\max } \pm \mathrm{s} . \mathrm{d}$ & $\mathrm{FPI}^{*} \pm$ s.e. & $\mathrm{FAI} \dagger \pm$ s.e. & $D_{\text {mitx }} \pm s . d$ & $\operatorname{FPI}^{\star} \pm$ s.e. & FAI $\dagger \pm$ s.e. \\
\hline $\begin{array}{c}\text { Vegetative } \\
\text { Mean } \\
\text { Range }\end{array}$ & $\begin{array}{c}3.41 \pm 0 \cdot 46 \\
2 \cdot 46 \quad 4 \cdot 30\end{array}$ & $0.92 \pm 0.09$ & $0.99 \pm 0.00$ & $\begin{array}{c}5 \cdot 76 \pm 1 \cdot 14 \\
3 \cdot 75-8 \cdot 29\end{array}$ & $0.95 \pm 0.02$ & $0.99 \pm 0.00$ & $\begin{array}{c}3.80 \pm 0.58 \\
2 \cdot 71-5.16\end{array}$ & $0.94 \pm 0.05$ & $0.99 \pm 0.00$ \\
\hline $\begin{array}{c}\text { Sporangia } \\
\text { Mean } \\
\text { Range }\end{array}$ & $\begin{array}{c}4.12 \pm 0.52 \\
3.34-5.10\end{array}$ & $0.95 \pm 0.02$ & $0.99 \pm 0.00$ & $\begin{array}{c}7 \cdot 20 \pm 1 \cdot 19 \\
5 \cdot 95-9 \cdot 11\end{array}$ & $0.96 \pm 0.01$ & $0.99 \pm 0.00$ & $\begin{array}{c}5.21 \pm 0.49 \\
4.83-5.92\end{array}$ & $0.90 \pm 0.06$ & $0.98 \pm 0.01$ \\
\hline $\begin{array}{c}\text { Autospore } \\
\text { Mean } \\
\text { Range }\end{array}$ & $\begin{array}{c}2.82 \pm 0.45 \\
1.95-3.93\end{array}$ & $0.84 \pm 0.07$ & $0.97 \pm 0.02$ & $\begin{array}{c}2.96 \pm 1.04 \\
0.69-5.61\end{array}$ & $0 \cdot 78 \pm 0 \cdot 10$ & $0.95 \pm 0.04$ & $\begin{array}{c}2.44 \pm 0.92 \\
0.98-3.94\end{array}$ & $0.85 \pm 0.08$ & $0.97 \pm 0.04$ \\
\hline
\end{tabular}

* FPI = Form Perimeter Indicator : 1 indicates regular spheric shape; $<-1$ indicates ellipsoidal or irregular shape.

† FAI = Form Area Indicator : I indicates spheric or ellipsoidal structures; $<1$ indicates irregular structures.

were initially provided with $28 \mathrm{~mm}$ glucose. $\mathrm{PH}$ conditions, which naturally occur under dim light when photosystem II does not work (Van Baalen, Hoare and Brandt, 1971), were reproduced in the laboratory by adding $10^{-5} \mathrm{M}$ DCMU [3(3,4-dichlorophenyl)-1,1-dimethylurea] under high light conditions according to Kenyon, Rippka and Stanier (1972).

\section{Acetolysis}

Cells were collected by centrifugation, dehydrated in ethanol and washed in glacial acetic acid. Acetolysis was then carried out in a boiling water bath, using nine parts acetic anhydride plus one part concentrated sulphuric acid, for 25 mins. Acetolysis-resistant residues were observed by light microscopy (Olympus BH-2, Olympus Optical Co. Ltd., Tokyo, Japan) after washing in glacial acetic acid and rehydrating in ethanol.

\section{Electron microscopy}

Cells were harvested in late exponential phase $(72 \mathrm{~h})$, when fully adapted to the different conditions of growth. Cells were collected by centrifugation, washed three times in $0.1 \mathrm{M}$ Na-phosphate buffer pH 7.2 (the same buffer was used throughout the whole procedure) and fixed in $3.125 \%$ glutaraldehyde in buffer for $3 \mathrm{~h}$ at $4^{\circ} \mathrm{C}$. Samples were washed three times in buffer and incorporated in $4 \%$ bacteriological agar in buffer before being cut into $1-2-\mathrm{mm}$ blocks. The agar blocks were post-fixed in $1 \%$ osmium tetroxide in buffer for $2 \mathrm{~h}$ at $4^{\circ} \mathrm{C}$. Samples were then dehydrated in ethanol and embedded in Spurr's (1969) resin (Agar Scientific Ltd., Essex, UK). Specimens were thinsectioned (Ultracut E, Reichert-Jung Ultratome, Austria), stained with lead citrate (Reynolds, 1963) and observed in a JEOL $100 \mathrm{~B}$ transmission electron microscope.

To demonstrate the lipidic nature of the electrodense grains found in the cytoplasm, a modification of the OTTO technique was carried out (Seligman, Wasserkrug and
Hanker, 1966). Ultrathin sections, mounted on nickel grids, were treated with $1 \%$ thiocarbohydrazide, for $1 \mathrm{~h}$ at $50{ }^{\circ} \mathrm{C}$ and, after washing in double distilled water, stained with $2 \%$ osmium tetroxide at $60^{\circ} \mathrm{C}$ for $1 \mathrm{~h}$ and washed again.

\section{Image analysis and stereological measurements}

A MOP-Videoplan (Kontron, Munich, Germany) semiautomatic digitizing image analysis system was used to quantify cell structure dimensions. Measurements were taken on 30 randomly chosen micrographs of cellular sections, from three to four resin blocks.

Stereological parameters were calculated from image analysis data on the second dimension by using the software 'Stereo' (Kontron, Munich, Germany). Stereological parameters presented here are:

$\mathrm{V}_{1}$ : Volume density (\%): the volume of the component related to the containing volume (e.g. $V_{V_{\text {mitochondron. eell }}}=$ percentage of total cell volume occupied by mitochondrion).

$S_{\mathrm{v}}$ : Surface density $\left(\mu \mathrm{m}^{2} \mu \mathrm{m}^{3}\right)$ : the surface area of the component per unit containing volume.

$\mathrm{S} / \mathrm{V}$ : Surface/volume ratio for the component considered ( $S / V=1$ for sphere; $S / V \geqslant 5$ for long and irregular structures).

$\mathrm{N}_{\mathrm{v}}$ : Numerical density: number of components per unit containing volume.

Except when otherwise indicated, the containing volume used as reference was the volume included in the cell wall perimeter.

In the case of the 'chloroplast active fraction' the volume of chloroplast minus the volume of chloroplastic starch grains was considered.

\section{RESULTS}

Cellular shape and size of Chlorella vulgaris UAM 101

Table 1 shows the diameter of the cells under different growth conditions (AC, MX and $\mathrm{PH}$ ) expressed separately 
TA B LE 2. Cell wall thickness of Chlorella vulgaris UAM 101 under different conditions of growth

\begin{tabular}{cc}
$\begin{array}{c}\text { Growth } \\
\text { conditions }\end{array}$ & $\begin{array}{c}\text { Mean cell wall } \\
\text { thickness (nm } \pm \text { s.d.) }\end{array}$ \\
\hline AC & $128 \pm 13$ \\
MX & $123 \pm 14$ \\
PH & $131 \pm 17$
\end{tabular}
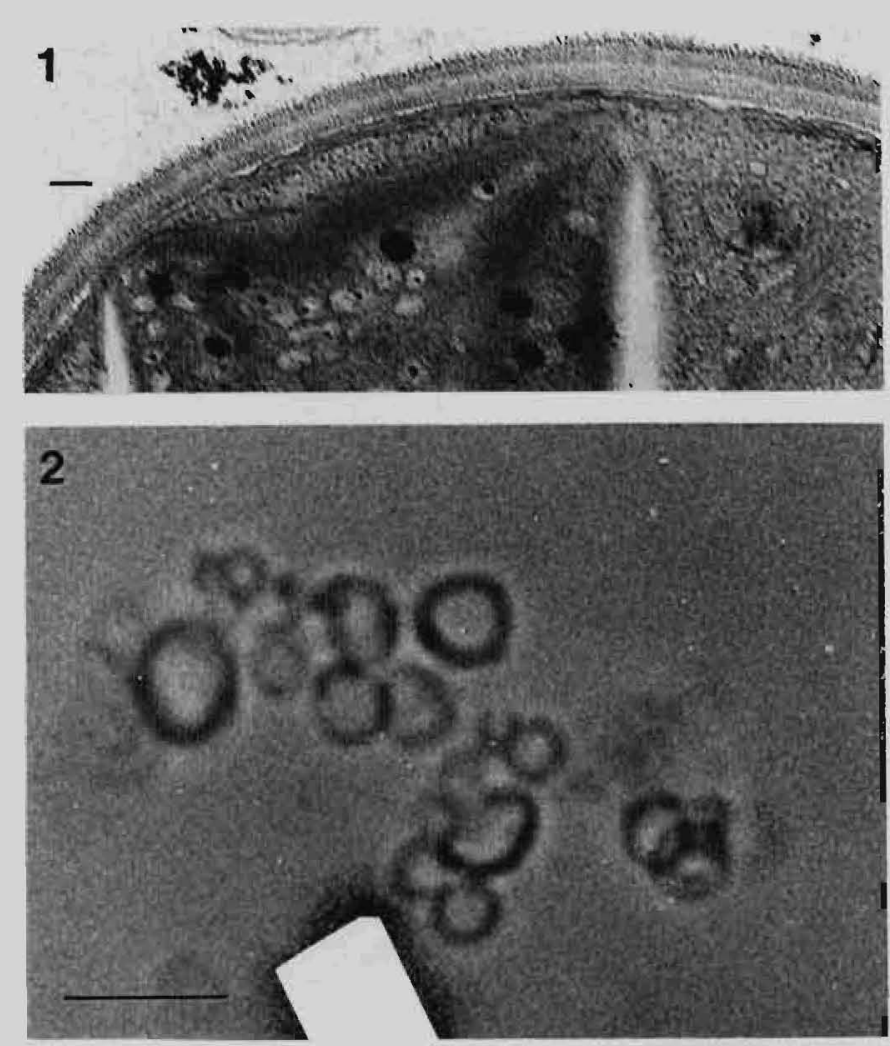

Fic. I. Electron micrograph detail of cell wall of an AC cell of Chlorella vulgaris UAM 101 showing the outer trilaminar layer and the inner microfibrilar layer. Bar $=100 \mathrm{~nm}$.

Fig. 2. Acelolysis resistant residues of C. vulgaris UAM 101, after 25 mins of treatment, observed under light microscopy (the photograph corresponds to an $\mathrm{AC}$ culture sample). Bar $=5 \mu \mathrm{m}$.

for vegetative cells, sporangia and autospores inside mother cells, for comparison with Chlorella vulgaris Beijerinck var. vulgaris iconotype (see Fott and Nováková, 1969). Cellular shape is determined by FPI (Form Perimeter Indicator) and FAI (Form Area Indicator) parameters (see footnotes to Table 1). Since the FAI indicates mostly regular spheric or ellipsoidal shapes of cells in each case, the FPI clearly indicates that vegetative cells and sporangia are mostly spherical, whereas autospores tend to be ellipsoidal. The same is true of AC and MX or PH cells. However, MX cells have larger diameter values indicating a significant increase in volume induced by glucose. Nevertheless, this effect on the cell volume does not affect the shape of the cells. The same effect occurs in PH sporangia and, to a lesser extent, in PI vegetative cells, although this is not so evident when the diameter rather than volume of the cells is considered (data not shown).

The data in this table also indicate that glucose induces the formation of more autospores per sporangium. This is a consequence of the cell cycle alteration promoted by glucose that will be detailed in a forthcoming publication correlating analytical, enzymatic and ultrastructural information.

\section{Cell wall}

The cell wall of our strain of Chlorella appears to be $120-130 \mathrm{~nm}$ thick (Table 2) and glucose does not appreciably affect this thickness. However, we have found some PH cells with a double cell wall (see Fig. 5). We think that the latter could be related to the higher $\beta-1,4$ endoglucanase activity and the cell division delay observed when glucose is present in the culture medium (unpubl. res.).

With respect to the ultrastructure of the cell wall (Fig. 1) our $C$. vulgaris has an inner microfibrilar layer of about $100-110 \mathrm{~nm}$ and an outer trilaminar layer approx. 20-30 nm thick. Since the presence of an outer trilaminar layer has been previously described in relation to the presence of sporopollenin in other Chlorella species (Atkinson et al., 1972), we decided to check this observation by acetolytic digestion of the cells. Figure 2 shows cellular ghosts that persist even after 25 mins of acetolytic treatment. Therefore, we must conclude that this $C$. vulgaris possesses sporopollenin in its cell wall.

\section{Chloroplast}

The chloroplast of this C. vulgaris (Figs 3, 4 and 5) appears mostly girdle-shaped or cup-shaped, although it is usually saucer-shaped in autospores (Fig. 6). It contains a pyrenoid, mostly lateral in relation to the chloroplast split, covered with saucer-shaped starch grains, the latter are also present separately in the stroma. It also contains plastoglobuli dispersed in the stroma.

In Fig. 7, volume densities of the chloroplast are shown for each growth condition analysed. When the $\mathrm{V}_{\mathrm{venh} \text { roplant, (e)11 }}$ (Fig. $7 \mathrm{~A}$, left) is considered, it seems that under $\mathrm{MX}$ conditions glucose affects the relative size of this organelle by increasing it. However, when only the active fraction of the chloroplast is determined, the data indicate that glucose does not significantly affect the $\mathrm{V}_{\mathrm{v} \text { enlorophast aet tve rraction, cell }}$ (Fig. 7 , right). Thus, the increase in the relative size of $M X$ chloroplasts is determined by the higher accumulation of starch grains under these conditions of growth (sec Fig. 8). However in PH cells, which do not accumulate extra starch grains, volume density of chloroplasts is not significantly different to that of the AC cells (Fig. $7 \mathrm{~A}$, left and right).

Plastoglobuli, however, appear most abundant in PH cell chloroplasts (Fig. 7B). The percentage of chloroplastic volume occupied by plastoglobuli in these cells is higher than in AC ones. The opposite occurs in MX cells, which have the lowest percentage of chloroplastic volume occupied by plastoglobuli. 

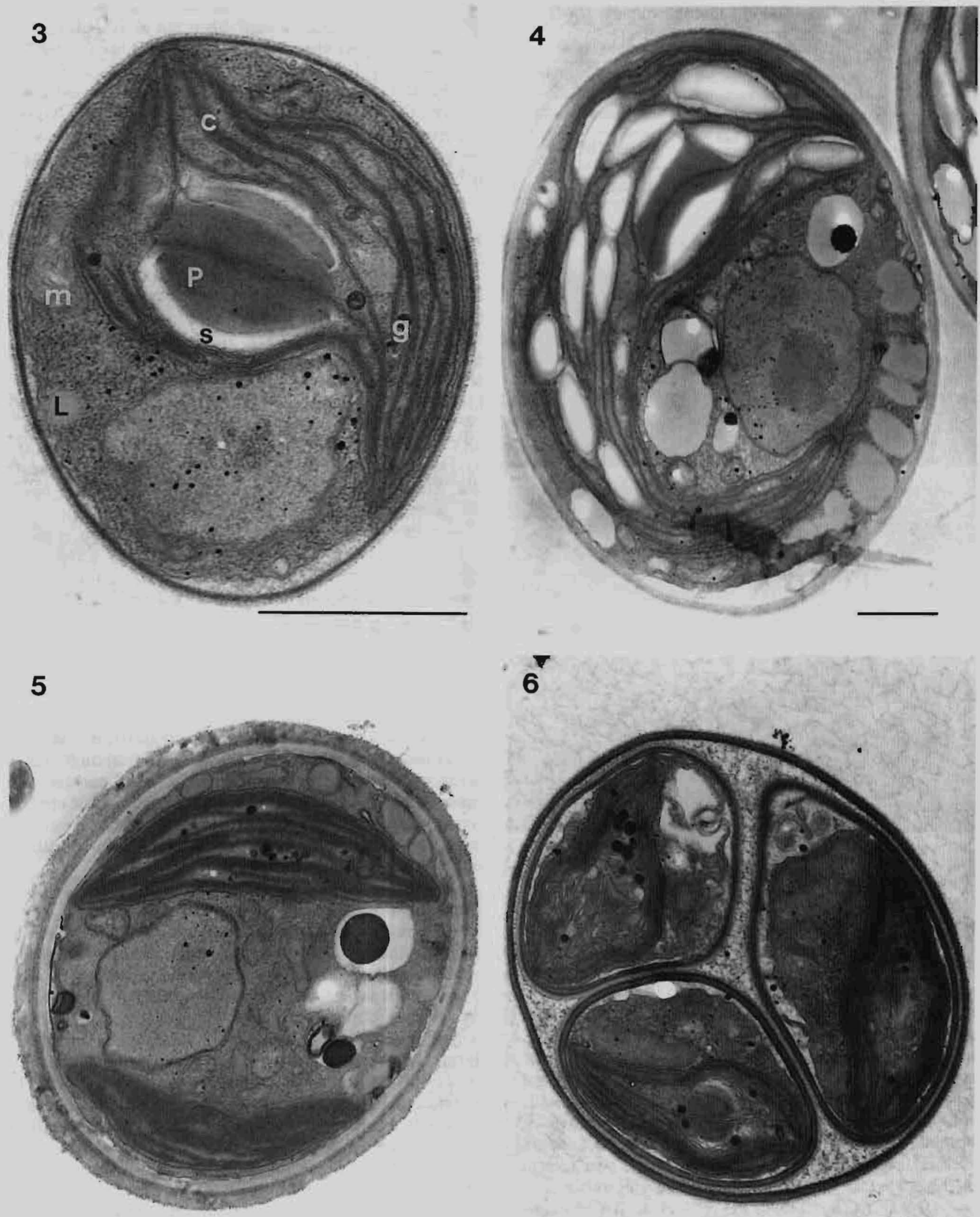


\section{Storage products}

Figure 8 indicates volume densities for storage products such as carbohydrates (starch grains) or lipids (lipid grains existing in the cytoplasm). The lipidic nature of such granules was confirmed by specific staining according to the Otto technique.

As described above, MX cells contain a high level of storage carbohydrates, unlike AC and PH cells. But this is not the only fraction that is increased in these cells. The percentage of total cell volume occupied by lipid grains in MX cells is almost three times higher than in AC cells. The same occurs in $\mathrm{PH}$ cells, although the increase in storage lipids is not so high.

\section{Mitochondrion}

Because of the special structure of the unique and highly fenestrated mitochondrion of Chlorella (Atkinson et al., 1974) we had to measure different parameters in order to determine possible ultrastructural changes under the different growth conditions.

Data in Table 3 indicate that the absolute volume of mitochondrion increases in MX cells, which have a higher area and a higher number of digitations (each one of the finger-like lobuli of Chlorella fenestrated mitochondrion, see Atkinson et al., 1974) than AC cells, and the same seems to occur in PH cells (lower area, but much higher number of digitations). However, the data on $\mathrm{V}_{\mathrm{v} \text { mituchonurtion, rell }}$ show that glucose does not significantly affect the relation between cell and mitochondrial volume. There is no change in the general organization of MX mitochondria, neither in the $\mathrm{S} / \mathrm{V}$ ratio nor in the surface in contact with cytoplasm. However, PH cells present a different mitochondrial organization, showing the highest numerical density of digitations, each digitation clearly having a smaller area and perimeter than those of the AC cells. Consequently, the PH mitochondria present a higher $\mathrm{S} / \mathrm{V}$ ratio and therefore, a larger surface in contact with cytoplasm $\left(\mathrm{S}_{\mathrm{v}}\right)$.

\section{DISCUSSION}

Most of the ultrastructural characteristics examined in this paper-cellular size and shape, chloroplast shape and pyrenoid location, presence and location of starch grains, etc.-coincide with those described for Chlorella vulgaris Beijerinck iconotype (Fott and Nováková, 1969). However, the cell wall of this species has been usually described as thin, lacking the outer trilaminar layer and with no sporopollenin in its composition (Fott and Nováková, 1969; Atkinson et al., 1972; Yamada and Sakaguchi, $1982 \mathrm{~b}$ ). This strain of C. vulgaris clearly possesses sporopollenin since acetolysis-resistant residues can be found after 25 mins of treatment. Moreover, the presence of the outer trilaminar layer (Fig. 1), which is closely related to the ability to synthesize secondary carotenoids and therefore sporopollenin (Atkinson et al, 1972; Yamada and Sakaguchi, 1982b; Rosen et al., 1985), confirms this statement. This could explain the cell wall thickness and structure we found, similar to that reported by Atkinson et al. (1972) for the strain Cambridge $211 / 8 \mathrm{p}$ of Chlorella fusca var. vacuolata, and our previous inability to permeabilize or break the cells by the usual methods described in the literature. Unless this strain does not belong to the species Chlorella vulgaris, this must indicate that the ability to synthesize secondary carotenoids is not a good taxonomic character.

As for the effect of glucose on the cell ultrastructure, the most drastic change seems to be the increase in the size of MX cells, determined by the higher metabolic activity observed in the presence of glucose and saturating light intensities (Orús and Martínez, 1990, Martínez and Orús, 1991). However, as shown in Table 1 , glucose does not affect cellular shape, confirming that an increase in cellular size is not determined by an osmotic effect but by the higher metabolic activity.

The volume density of chloroplasts was apparently higher in $\mathrm{MX}$ than in AC cells. In fact, the photosynthetic activity of these cells is stimulated by glucose (Orús and Martínez, 1990) and, therefore, such an increase would not be surprising. However, volume density of the chloroplast active fraction indicates that the higher relative chloroplastic volume is only a consequence of a larger amount of storage carbohydrates, while pyrenoid and thylakoid membranes remain in the same proportions as in AC cells. The fact that glucose does not affect the relative size of the photosynthetic structures while it does stimulate the photosynthetic rate, indirectly supports our previous hypothesis that the $\mathrm{CO}_{2}$ arising from glucose respiration acts as an alternative source for the inorganic carbon fixation process (Martínez and Orús, 1991).

Something similar occurs with the mitochondrion. It has been stated that in obligate heterotrophs, such as Polytoma papillatum (Gaffal, 1978) or Polytomella agilis (Burton and Moore, 1974), mitochondria occupy a larger fraction of cel] volume than in photolithotrophic algae. In this facultative heterotroph, C. vulgaris UAM 101, the absolute size of MX cell mitochondrion appears clearly larger than $A C$ cell mitochondrion, as indicated by the perimeter and area of each single digitation or numerical density $\left(\mathrm{N}_{\mathrm{v}}\right)$ of them. However, the volume density of the organelle remains constant under any condition. Nevertheless, as shown in Table 3, PH cells did present a different organization of their mitochondria, which exhibited a larger surface in contact with the cytoplasm due to a higher degree of fenestration. This might be related to the higher dependence of $\mathrm{PH}$ cells on the exogenous glucose, since they are unable to obtain reducing power from photosynthesis. This is

FIG. 3. Electron micrograph of cross section of AC vegetative cell of $C$. vulgaris UAM 101. c, chloroplast; m, mitochondrion; P, pyrenoid; s, starch grain; L, lipid grain; g, plastoglobuli. Bar $=1 \mu \mathrm{m}$.

Fig. 4. Electron micrograph of cross section of $\mathrm{MX}$ vegetative cell of $C$. vulgaris UAM $101 . \mathrm{Bar}=1 \mu \mathrm{m}$.

FIG. 5. Electron micrograph of cross section of $\mathrm{PH}$ vegetative cell of $C$. vulgaris UAM 101 . Bar $=1 \mu \mathrm{m}$.

Fig. 6. Electron micrograph of cross section of AC mother cell of autospores of $C$. vulgaris UAM 101 . Bar $=1 \mu \mathrm{m}$. 


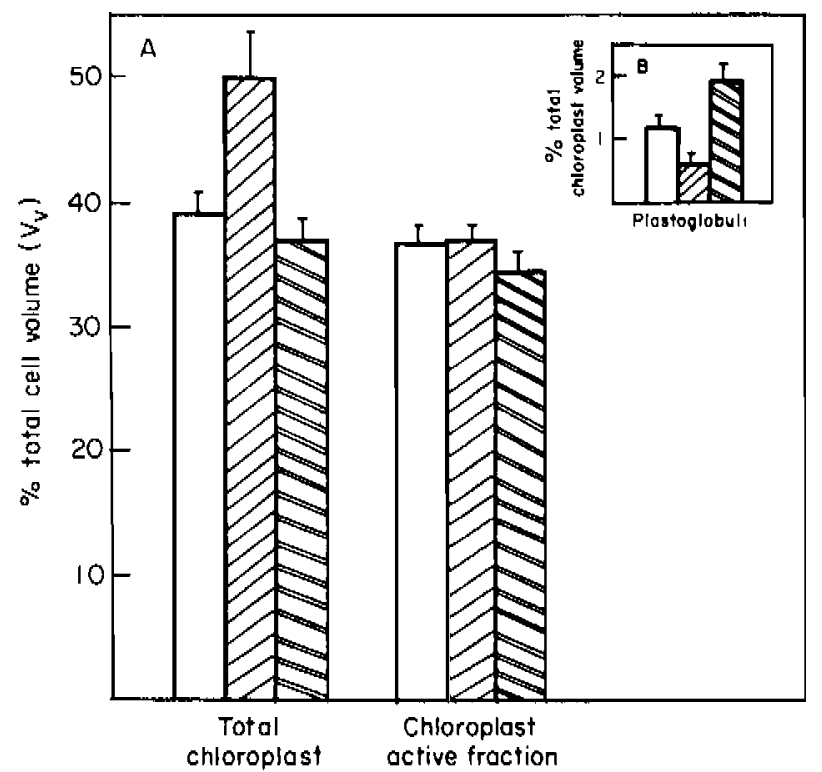

FIG. 7. A, Percentage of total cell volume occupied by the total chloro-

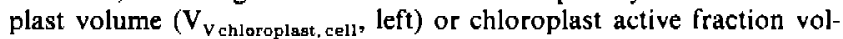

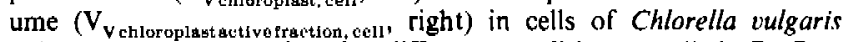
UAM 101 grown under the different conditions studied. B, Percentage of total chloroplastic volume occupied by plastoglobuli $\left(\mathrm{V}_{\mathrm{V} \text { plastoglobult, ohloroplast }}\right)$ in cells of Chlorella vulgaris UAM 101 grown under different conditions. $\square$ AC conditions; $\square$ MX conditions; $\mathbb{P}$ PH conditions. Vertical bars represent s.d.

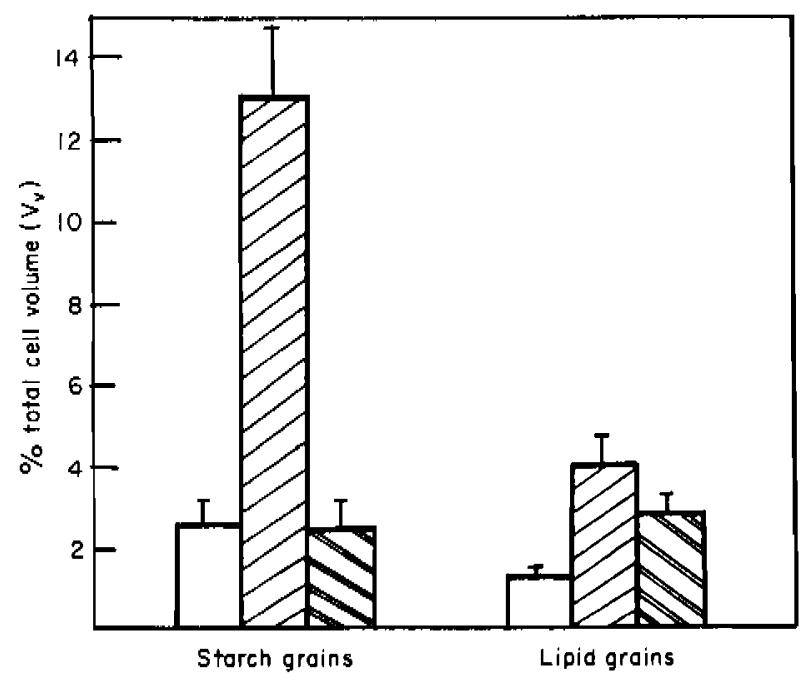

FIG. 8. Volume densities of starch chloroplastic grains (left) and lipid cytoplasmic grains (right) in C. vulgaris UAM 101 under : $\square$ AC conditions; $\square \mathrm{MX}$ conditions; $\mathbf{P H}$ conditions. Vertical bars represent s.d.

probably the reason why $\mathrm{PH}$ cells did not accumulate extra chloroplastic starch grains, unlike MX cells which show high photosynthetic activity simultaneously with exogenous glucose assimilation (Orús and Martinez, 1990) thus providing an extra source of carbon skeletons.

Under MX conditions, the high input of carbon skeletons (newly synthesized plus glucose uptake) explains that not only starch but also storage lipids are increased. The
TABLE 3. Morphometric and stereologic parameters of Chlorella vulgaris UAM 101 mitochondrion under different conditions of growth

\begin{tabular}{lrrr}
\hline \multicolumn{1}{c}{ Parameters } & AC & MX & PH \\
\hline $\mathrm{V}_{\mathrm{v}}(\%)$ & $3.99 \pm 0.19$ & $3.08 \pm 0.22$ & $3.91 \pm 0.11$ \\
$\mathrm{~N}_{\mathrm{v}}$ & $1.60 \pm 0.07$ & $4.67 \pm 0.19$ & $5.33 \pm 0.24$ \\
Mean perimeter per digitation & $1.49 \pm 0.06$ & $1.75 \pm 0.07$ & $1.09 \pm 0.03$ \\
$(\mu \mathrm{m})$ & & & $(\mathrm{P} \leqslant 0.05) \dagger$ \\
Mean area per digitation & $0.14 \pm 0.01$ & $0.16 \pm 0.01$ & $0.07 \pm 0.00$ \\
$\left(\mu \mathrm{m}^{2}\right)$ & $13.51 \pm 0.67$ & $13.52 \pm 0.75$ & $(\mathrm{P} \leqslant 0.05) \dagger$ \\
$\mathrm{S}_{\mathrm{V}} \mathrm{V}^{*}$ & $0.54 \pm 0.01$ & $0.41 \pm 0.02$ & $0.72 \pm 0.03$ \\
$\mathrm{~S}_{\mathrm{v}}\left(\mu \mathrm{m}^{2} \mu \mathrm{m}^{-3}\right)$ & & & \\
\hline
\end{tabular}

* $\mathrm{S} / \mathrm{V}=1$ for sphere; $\mathrm{S} / \mathrm{V} \geqslant 5$ for long and irregular structures.

† Student's $t$-test (with AC case), $n=30$.

enhancement of lipid content under $\mathrm{PH}$ conditions of growth is more difficult to interpret. Since PH cells are unable to synthesize new carbon skeletons because their photosynthesis only generates ATP but not reducing power, it would seem more understandable that they accumulate carbohydrates rather than lipids from the surplus of exogenous glucose. The only advantage of the preferential synthesis of lipid grains might be their cytoplasmic location which does not require glucose transport to the chloroplast.

On the other hand, plastoglobuli have been related to lipid accumulation from membrane breakdown during chloroplast senescence (Biswal and Biswal, 1988). However, this hypothesis is not consistent with the contradictory data we found in $\mathrm{MX}$ and $\mathrm{PH}$ cells when compared to that of the AC ones, since no degenerative symptoms can be observed in these cultures.

Glucose promotes drastic changes in the physiology and metabolism of the facultative heterotroph Chlorella vulgaris UAM 101 (Orús and Martínez, 1990, Martínez and Orús, 1991). However, the volume densities of the most relevant organelles, chloroplast and mitochondrion, do not change. It seems that volumetric ratios are quite constant and characteristic of each species. If this is true, stereological measurements could be a very useful additional tool for taxonomical purposes, especially since they can now be easily carried out by computer-supported techniques.

\section{ACKNOWLEDGEMENTS}

We thank Mrs M. J. Villoslada and Mr F. Pinto for technical assistance. This work was supported by a grant from the Comisión Asesora de Investigación Científica y Técnica (CAICYT).

\section{LITERATURE CITED}

Atkinson, A. W., JR., Gunning, B. E. S. and John, P. C. L., 1972. Sporopollenin in the cell wall of Chlorella and other algae: Ultrastructure, chemistry, and incorporation of ${ }^{14} \mathrm{C}$-acetate, studied in synchronous cultures. Planta 107, 1-32.

John, P. C. L. and GunNing, B. E. S., 1974. The growth and division of the single mitochondrion and other organelles during the cell cycle of Chlorella, studied by quantitative stereology and three-dimensional reconstruction. Protoplasma 81, 77-109. 
Biswal, U. C. and BiswaL, B., 1988. Ultrastructural modifications and biochemical changes during senescence of chloroplasts. International Review of Cytology 113, 271-321.

BURTON, M. D. and MOORE, J., 1974. The mitochondrion of the flagellate Polytomella agilis. Journal of Ultrastructural Research 48. 414-419.

FotT, B. and Novákoví, M., 1969. A monograph of the genus Chlorella. The fresh water species, pp. 10-74. In Studies in Phycology, ed. B. Fott. Schweizerbart'sche Verlagsbuchhandlung, Stuttgart.

Gaffal, K. P., 1978. Configural changes in plastidome of Polytoma papillatum after completion of cytokinesis and during fusion of gametes. Protoplasma 94, 175-192.

Kenyon, C. N., Rippka, R. and Stanier, R. Y., 1972. Fatty acid composition and physiological properties of some filamentous blue-green algae. Archiv für Mikrobiologie 83, 216-236.

Kessler, E., 1978. Physiological and biochemical contributions to the taxonomy of the genus Chlorella XII. Starch hydrolysis and a key for the identification of 13 species. Archives of Microhiology 119 , 1316.

Martínez, F., Avendaño, M. C., Marco, E. and Orús, M. I., 1987. Algal population and auxotrophic adaptation in a sugar refinery wastewater environment. Journal of General and Applied Microbiology 33, 331-341.

- and ORús, M. I., 1991. Interactions between glucose and inorganic carbon metabolism in Chlorella vulgaris strain UAM 101. Plant Physiology (in press).

Orús, M. I. and Martínez, F., 1990. Suitability of Chlorella vulgaris UAM 101 for heterotrophic biomass production. Biomass (in press).
Pickett-Heaps, J. D., 1975. The Chlorococcales, pp. 69 165. In Green Algae. Structure, Reproduction and Evolution in Selected Genera. Sinauer Associates Inc. Publishers, Sunderland, MA.

Raven, J. A., 1980. Nutrient transport in microalgae. Advances in Microbial Physiology 21, 47-226.

Reynolds, E. S., 1963. The use of lead citrate at high $\mathrm{pH}$ as an electron-opaque stain in electron microscopy. Journal of Cell Biology 17, 208-2I2.

Rodríguez-LóPEZ, M, 1964. Influence of the inoculum and the medium on the growth of Chlorella pyrenoidosa. Nature 203, 666-667.

Rosen, B. H., Berliner, M. D. and Petro, M. J., 1985. Protoplast induction in Chlorella pyrenoidosa. Plant Science 41, 23-30.

Seligman, A. M., Wasserkrug, H. L. and Hanker, J, S, 1966. A new staining method (Otto) for enhancing contrast of lipid-containing membranes and droplets in osmium tetroxide-fixed tissue with osmiophilic thiocarbohydrazine (TCH). Journal of Cell Biology 30, $424-432$.

SPURR, A. R,, 1969, A low-viscosity epoxy resin embedding medium for electron microscopy. Journal of Ultrastructural Research $\mathbf{2 6}$, $31-43$.

Van Baalen, C., Hoare, D. S. and Brandt, E., 1971. Heterotrophic growth of blue-green algae in dim light. Journal of Bacteriology $105,685-689$.

Yamada, T. and SaKaguchi, K., $1982 a$. Electron microscopic studies of Chlorella ellipsoidea protoplast formation. Journal of General Microbiology 128, 1319-1327.

- 1982b. Comparative studies on Chlorella cell walls: Induction of protoplast formation. Archives of Microbiology 132, $10-13$. 